\title{
Association Between Urinary Tract Infection in the First Trimester and Risk of Preeclampsia: A Case-Control Study
}

This article was published in the following Dove Press journal: International Journal of Women's Health

\author{
Aazam Taghavi Zahedkalaei' \\ Mahdiye Kazemi ${ }^{2}$ \\ Pouneh Zolfaghari ${ }^{3}$ \\ Marjan Rashidan (D) ${ }^{4}$ \\ Mohammad Bagher Sohrabi $\mathbb{D}^{5}$ \\ 'Department of Obstetrics and \\ Gynecology, Bahar Center for Education, \\ Research and Treatment, Shahroud \\ University of Medical Sciences, Shahroud, \\ Iran; ${ }^{2}$ Student Research Committee, \\ School of Medicine, Shahroud University \\ of Medical Sciences, Shahroud, Iran; \\ ${ }^{3}$ Vice-Chancellery of Health, Shahroud \\ University of Medical Sciences, Shahroud, \\ Iran; ${ }^{4}$ Department of Microbiology, \\ School of Medicine, Shahroud University \\ of Medical Sciences, Shahroud, Iran; \\ ${ }^{5}$ School of Medicine, Shahroud University \\ of Medical Sciences, Shahroud, Iran
}

Correspondence: Mohammad Bagher Sohrabi

School of Medicine, Shahroud University of Medical Sciences, Shahroud, Iran Tel +982332395054

Fax +982332394800

Emailmb.sohrabi@yahoo.com
Background: Urinary tract infection (UTI) is a common clinical problem during pregnancy that can have serious consequences for the mother and fetus. Some studies have suggested that UTI can trigger or aggravate preeclampsia. The present study aimed to investigate the association between urinary tract infection in the first trimester and the risk of preeclampsia in pregnant women referring to Bahar hospital of Shahroud.

Patients and Methods: In this case-control study, 92 pregnant women with a diagnosis of preeclampsia were selected as cases, and for comparison 92 pregnant women were selected as control. History of previous UTI in the first trimester was assessed as a risk factor. Data were analyzed using SPSS 16 software and related statistical tests such as mean and standard deviation, chi-square, and independent $t$-test.

Results: In this study, the mean age of the patients was $28.6 \pm 6.9$ years that no significant differences were found between the two groups. It was also found that $37(40.2 \%)$ patients in the case group and $29(31.5 \%)$ patients in the control group had a UTI which was significantly $(p<0.043)$ higher in the case group. Also, in the multivariate regression model, UTI was significantly associated with preeclampsia $(\mathrm{p}<0.048)$, so that UTI increases the risk of preeclampsia $(\mathrm{OR}=1.86)$.

Conclusion: The results of this study showed UTI during the first trimester of pregnancy is associated with the risk of preeclampsia. Therefore, controlling and treatment of urinary infections can reduce the risk of preeclampsia in the later months.

Keywords: urinary tract infection, preeclampsia, pregnancy

\section{Introduction}

Urinary tract infection (UTI) is a common clinical problem that accounts for about $1-6 \%$ of medical referrals to hospitals. UTI may be symptomatic or asymptomatic while asymptomatic bacteriuria (ASB), however, is important due to the absence of specific symptoms. ${ }^{1}$ UTI and its associated complications cause 150 million deaths annually worldwide. ${ }^{2}$ In pregnant women, physiological and anatomical changes in the urinary tract, as well as immune system changes during pregnancy, increase the incidence of ASB, and in some cases; it causes a symptomatic infection that can pose serious risks to the mother and fetus. Increased age, gestational rating, diabetes, sickle cell anemia, a history of UTI, urinary tract disorders, and immune deficiencies may increase the risk of UTI in pregnant women. ${ }^{3,4}$ UTI is the growth of bacteria in the urinary tract that can cause damage to the urinary tract and occurs when the number of bacteria in one $\mathrm{mL}$ of urine is $10^{5}$ or more. ${ }^{4,5} \mathrm{UTI}$; includes 
infections of the lower urinary tract (urinary tract and bladder) and upper urinary tract (kidney). Women are very susceptible to UTI. Twenty percent of women develop UTI at least once in their lives. The overall prevalence of bacteriuria in Iranian pregnant women has been reported at 2 to $41 \%$. Pregnancy increases the chance of getting a UTI that way it is the most common bacterial infection in pregnancy that may be asymptomatic or asymptomatic. ${ }^{5}$

UTI in pregnancy has been considered as a risk factor for adverse maternal and perinatal outcomes. ${ }^{6}$ In several studies the relationship between UTI and preterm labor, low birth weight, perinatal mortality, neonatal heart abnormalities, mental retardation, delayed infant development, maternal hypertension, preeclampsia, maternal anemia, infection amniotic fluid and endometritis have been reported. ${ }^{6-9}$ Preeclampsia (PE) is one of the most common complications of pregnancy and a lack of timely diagnosis and treatment can cause maternal and fetal complications. ${ }^{10}$ The incidence of preeclampsia is $5 \%$ but considerable variation has been reported in this area. Blood pressure disorders in pregnancy and severe hemorrhage and infections, which are three main causes of pregnancyrelated morbidity and mortality. ${ }^{10,11}$ Timely and rapid diagnosis and treatment can reduce its maternal and fetal complications. $^{12}$

Preeclampsia is a multisystemic vascular syndrome of pregnancy that was characterized by high blood pressure and proteinuria that typically occurs after week 20 of pregnancy. ${ }^{13} \mathrm{PE}$ affects in 0.2 to $9.2 \%$ pregnant women. ${ }^{5}$ Although the exact cause of PE is unknown, over activation of the systemic inflammatory response plays a key role in its pathogenesis. ${ }^{14}$ Thought to be, UTI is thought to play an important role in PE by helping to enhance the maternal systemic inflammatory response. ${ }^{14,15}$ Despite widespread research into the etiology of preeclampsia and its high morbidity and morbidity during pregnancy, all mechanisms that cause preeclampsia not exactly clear, but the most common cause is abnormal placenta due to abnormal perfusion. ${ }^{16}$ Given the relatively high prevalence of preeclampsia in Shahroud, and concerning its importance, this study was conducted to investigate the association between urinary tract infection and preeclampsia in pregnant women referred to Bahar hospital in Shahroud during 2019.

\section{Patients and Methods}

This case-control study was performed on pregnant women referring to Bahar hospital of Shahroud between January and December 2019. All eligible patients were divided into two equal case groups (with preeclampsia) and the control group (without preeclampsia). Sampling continued in an easy and accessible manner until the sample size was completed for each group.

Case group characteristics included preeclampsia, no history of kidney disease normal pregnancy and the characteristics of the control group included no preeclampsia, no history of kidney disease, single and normal pregnancy.

The criteria for the diagnosis of preeclampsia included: blood pressure equal to or greater than 140/90 $\mathrm{mmHg}$ after 20 weeks of pregnancy and proteinuria equal to or greater than $300 \mathrm{mg}$ in 24 hours or equal to or greater than 1 plus in the urinary strip. ${ }^{10,11}$

The exposure of this study was a previous urinary tract infection in the first trimester. History of UTI was assessed using a review of previous medical records, laboratory, and insurance documents.

Also, the other variables such as age, sex, history of diabetes, hypertension, kidney disease, and history of smoking were compared between the two groups.

Descriptive statistics including mean and standard deviation, as well as relative frequency were used to describe the data. To examine the relationships and comparisons between the two groups was used the chi-square test and multivariate logistic regression were used to evaluate the odds of each of the variables. All analyzes were performed using SPSS software version 16 and a significant level $(p<0.05)$.

Sample size using Epi info 7.2 at a significant level of $5 \%$ and a power of $80 \%$, equal to 92 people in each group and a total of 184 people.

This study has an ethics code number (IR.SHMU. REC.1397.85) from the research deputy of Shahroud University of Medical Sciences. The essential information and the objectives of the study were explained to the patients, and written consent was obtained for participation in the plan. It should be noted that this study was conducted in accordance with the Helsinki Declaration.

\section{Results}

In this study, the mean age of the patients was $28.6 \pm 6.9$ years that the age group of 18-35 years old with $61.9 \%$ had the highest frequency among patients in both groups that no significant differences were found between the two groups. The mean gestational age of the patients was 28.6 $30.5 \pm 4.5$ weeks that were no different. It was also found that $37(40.2 \%)$ patients in the case group and 29 (31.5\%) patients in the control group had a UTI which was significantly $(p<0.043)$ higher in the case group. The results 
Table I Comparison of Demographic Data and Clinical Variables in Case and Control Groups

\begin{tabular}{|c|c|c|c|}
\hline Variables & $\begin{array}{l}\text { Case Group } \\
\text { Number (\%) }\end{array}$ & $\begin{array}{l}\text { Control Group } \\
\text { Number (\%) }\end{array}$ & $\begin{array}{l}\mathrm{P} \\
\text { value }\end{array}$ \\
\hline Mean age (years) & $29.3 \pm 6.5$ & $27.7 \pm 7.4$ & 0.072 \\
\hline $\begin{array}{l}\text { Age groups (years) } \\
\qquad 18 \\
18-35 \\
>35\end{array}$ & $\begin{array}{l}13(14.1) \\
56(60.8) \\
23(25.1)\end{array}$ & $\begin{array}{l}15(16.3) \\
58(63.1) \\
19(20.6)\end{array}$ & 0.128 \\
\hline BMI $\left(\mathrm{kg} / \mathrm{m}^{2}\right)$ & $25.8 \pm 3.6$ & $24.7 \pm 3.4$ & 0.093 \\
\hline $\begin{array}{l}\text { BMl groups }\left(\mathrm{kg} / \mathrm{m}^{2}\right) \\
\quad<18 \\
18-25 \\
>25\end{array}$ & $\begin{array}{l}9(9.8) \\
67(72.8) \\
16(17.4)\end{array}$ & $\begin{array}{l}11(11.9) \\
66(71.7) \\
15(16.4)\end{array}$ & 0.123 \\
\hline $\begin{array}{l}\text { Education } \\
\text { Less than a diploma } \\
\text { Diploma } \\
\text { Academic }\end{array}$ & $\begin{array}{l}19(20.6) \\
33(35.8) \\
40(43.5)\end{array}$ & $\begin{array}{l}15(16.3) \\
35(38.1) \\
42(45.6)\end{array}$ & 0.141 \\
\hline $\begin{array}{l}\text { Habitancy site } \\
\text { City } \\
\text { Village }\end{array}$ & $\begin{array}{l}66(71.7) \\
26(28.3)\end{array}$ & $\begin{array}{l}68(73.9) \\
24(26.1)\end{array}$ & 0.108 \\
\hline $\begin{array}{l}\text { Parity } \\
\text { Null Parity } \\
\text { Multi Parity }\end{array}$ & $\begin{array}{l}29(31.5) \\
63(68.5)\end{array}$ & $\begin{array}{l}34(36.9) \\
58(63.1)\end{array}$ & 0.059 \\
\hline $\begin{array}{l}\text { Type of pregnancy } \\
\text { Singleton } \\
\text { Multiple pregnancy }\end{array}$ & $\begin{array}{l}11(11.9) \\
81(88.1)\end{array}$ & $\begin{array}{l}14(15.2) \\
78(84.8)\end{array}$ & 0.088 \\
\hline Mean gestational age (week) & $31.4 \pm 4.1$ & $29.5 \pm 4.9$ & 0.069 \\
\hline $\begin{array}{l}\text { Gestational age groups } \\
\text { (week) } \\
20-26 \\
26-32 \\
>32\end{array}$ & $\begin{array}{l}17(18.5) \\
49(53.2) \\
26(28.3)\end{array}$ & $\begin{array}{l}19(20.6) \\
52(56.5) \\
21(22.9)\end{array}$ & 0.104 \\
\hline $\begin{array}{l}\text { UTI } \\
\text { Positive } \\
\text { Negative }\end{array}$ & $\begin{array}{l}37(40.2) \\
55(59.8)\end{array}$ & $\begin{array}{l}29(31.5) \\
63(68.5)\end{array}$ & 0.043 \\
\hline $\begin{array}{l}\text { History of diabetic } \\
\text { Yes } \\
\text { No }\end{array}$ & $\begin{array}{l}13(14.1) \\
79(85.9)\end{array}$ & $\begin{array}{l}11(11.9) \\
81(88.1)\end{array}$ & 0.121 \\
\hline $\begin{array}{l}\text { History of hypertension } \\
\text { Yes } \\
\text { No }\end{array}$ & $\begin{array}{l}26(28.2) \\
66(71.8)\end{array}$ & $\begin{array}{l}25(27.2) \\
67(72.8)\end{array}$ & 0.107 \\
\hline $\begin{array}{l}\text { History of kidney disease } \\
\text { Yes } \\
\text { No }\end{array}$ & $\begin{array}{l}3(3.2) \\
89(96.8)\end{array}$ & $\begin{array}{l}5(5.4) \\
87(94.6)\end{array}$ & 0.103 \\
\hline $\begin{array}{l}\text { History of smoking } \\
\text { Yes } \\
\text { No }\end{array}$ & $\begin{array}{l}10(10.8) \\
82(89.2)\end{array}$ & $\begin{array}{l}8(8.7) \\
84(91.3)\end{array}$ & 0.083 \\
\hline
\end{tabular}

(Continued)
Table I (Continued).

\begin{tabular}{|l|l|l|l|}
\hline Variables & $\begin{array}{l}\text { Case Group } \\
\text { Number (\%) }\end{array}$ & $\begin{array}{l}\text { Control Group } \\
\text { Number (\%) }\end{array}$ & $\begin{array}{l}\mathbf{p} \\
\text { value }\end{array}$ \\
\hline Mean proteinuria (gram/24h) & $357.5 \pm 75.5$ & $94.7 \pm 20.9$ & 0.001 \\
\hline $\begin{array}{l}\text { Proteinuria category } \\
\text { (gram/24h) }\end{array}$ & & & \\
$<300$ & $3(3.2)$ & $85(92.4)$ & 0.001 \\
$300-500$ & $72(78.2)$ & $7(7.6)$ & \\
$>500 /$ & $18(19.6)$ & $0(0.0)$ & \\
\hline $\begin{array}{l}\text { Pregnancy outcomes } \\
\text { Normal baby }\end{array}$ & $73(79.3)$ & $84(91.3)$ & 0.053 \\
Baby with a serious disorder & $16(17.4)$ & $7(7.6)$ & \\
Dead baby & $3(3.3)$ & $1(1.1)$ & \\
\hline
\end{tabular}

Note: Bold face indicates values that are significant $(p<0.05)$.

of demographic factors and clinical history of pregnant women in both groups are shown in Table 1. In this study, independent variables with preeclampsia were investigated in the multivariate regression model. As shown in Table 2, preeclampsia variables were significantly associated with UTI $(\mathrm{p}<0.048)$ so that UTI increases the risk of preeclampsia $[\mathrm{OR}=1.86$, $(95 \%$ Confidence: 2.235-1.608)] and there was no significant relationship with other variables. The results of the multivariate logistic regression model are presented in Table 2.

\section{Discussion}

The results of this study showed that urinary tract infection can significantly increase the incidence of preeclampsia in pregnant women and even increase the chance of its occurrence by 1.8 times. The results are somewhat consistent with the findings of the Karmon study, ${ }^{16}$ but conflict with the results of the Herrera and Easter studies which may be due to differences in climatic and health conditions in Iran with other countries. ${ }^{17,18}$

The factor affecting the development of PE may be due to the initial trophoblastic invasion and the maternal response to it. Failure of normal invasion of trophoblastic cells results in incorrect adaptation of the spiral arteries associated with the causes of PE. ${ }^{19}$

The results of this study showed that there was no significant difference between the age groups of patients and the incidence of preeclampsia. It was also found that age could not increase the chance of preeclampsia in women with UTI. Zibaeenazhad et al reported that young women over 35 years of age were more likely to have hypertension and a higher chance of PE. ${ }^{20}$ Sheraz et al 
Table 2 Relationship Between Independent Variables with Preeclampsia in Multivariate Logistic Regression Model

\begin{tabular}{|c|c|c|c|c|}
\hline \multicolumn{2}{|l|}{ Independent Variables } & \multirow{2}{*}{$\begin{array}{l}\text { OR } \\
1.000 \\
1.089 \\
1.196\end{array}$} & \multirow{2}{*}{$\begin{array}{l}95 \% \mathbf{C l} \\
1.342-0.0652 \\
1.451-0.0912\end{array}$} & \multirow{2}{*}{$\begin{array}{l}\mathbf{P} \text { value } \\
0.074 \\
0.055\end{array}$} \\
\hline Age category & $\begin{array}{l}18 \text { to } 35 \text { years } \\
\text { Less than } 18 \text { years } \\
\text { More than } 35 \text { years }\end{array}$ & & & \\
\hline BMI $\left(\mathrm{kg} / \mathrm{m}^{2}\right)$ & $\begin{array}{l}18-25 \\
<18 \\
>25\end{array}$ & $\begin{array}{l}1.000 \\
1.098 \\
1.054\end{array}$ & $\begin{array}{l}1.183-0.825 \\
1.129-0.968\end{array}$ & $\begin{array}{l}0.098 \\
0.073\end{array}$ \\
\hline Degree of education & $\begin{array}{l}\text { Under the diploma } \\
\text { Diploma } \\
\text { Academic }\end{array}$ & $\begin{array}{l}1.000 \\
0.923 \\
0.875\end{array}$ & $\begin{array}{l}1.125-0.756 \\
1.035-0.612\end{array}$ & $\begin{array}{l}0.055 \\
0.051\end{array}$ \\
\hline Pregnancy rating & $\begin{array}{l}\text { Noli Parity } \\
\text { Multi Parity }\end{array}$ & $\begin{array}{l}1.000 \\
1.091\end{array}$ & I. $|73-0.87|$ & 0.071 \\
\hline Gestational age groups (week) & $\begin{array}{l}20-26 \\
26-32 \\
>32\end{array}$ & $\begin{array}{l}1.000 \\
1.105 \\
1.284\end{array}$ & $\begin{array}{l}1.248-0.811 \\
1.439-0.986\end{array}$ & $\begin{array}{l}0.085 \\
0.057\end{array}$ \\
\hline Type of pregnancy & $\begin{array}{l}\text { Singleton } \\
\text { Multiple pregnancy }\end{array}$ & $\begin{array}{l}1.000 \\
1.109\end{array}$ & $1.305-0.95 \mid$ & 0.095 \\
\hline History of UTI & $\begin{array}{l}\text { Negative } \\
\text { Positive }\end{array}$ & $\begin{array}{l}1.000 \\
1.855\end{array}$ & $2.235-1.608$ & 0.048 \\
\hline History of kidney disease & $\begin{array}{l}\text { Negative } \\
\text { Positive }\end{array}$ & $\begin{array}{l}1.000 \\
1.089\end{array}$ & $1.263-0.916$ & 0.93 \\
\hline History of diabetic & $\begin{array}{l}\text { Negative } \\
\text { Positive }\end{array}$ & $\begin{array}{l}1.000 \\
1.326\end{array}$ & $2.142-1.309$ & 0.0109 \\
\hline History of hypertension & $\begin{array}{l}\text { Negative } \\
\text { Positive }\end{array}$ & $\begin{array}{l}1.000 \\
1.028\end{array}$ & $1.282-0.857$ & 0.101 \\
\hline History of smoking & $\begin{array}{l}\text { Negative } \\
\text { Positive }\end{array}$ & $\begin{array}{l}1.000 \\
2.412\end{array}$ & $3.405-1.587$ & 0.008 \\
\hline Pregnancy outcome & $\begin{array}{l}\text { Normal baby } \\
\text { Abnormal baby }\end{array}$ & $\begin{array}{l}1.000 \\
1.247\end{array}$ & $1.562-0.932$ & 0.054 \\
\hline
\end{tabular}

Note: Bold face indicates values that are significant $(p<0.05)$.

reported that $\mathrm{PE}$ was more common in patients younger than 21 years and above 35 years. ${ }^{21}$ Kumar et al showed that pregnant women younger than 18 years were 3.87 times more at risk of PE than those over 18 years of age. ${ }^{22}$ Sajith et al reported that the highest prevalence of pregnancy hypertension was observed in the 22-28 age group with $41.3 \% .{ }^{23}$ As can be seen, the results of these studies are different from the findings of the present study that perhaps the most important reasons for this difference relate to geographical, cultural, nutritional differences as well as the sample size of studies.

In our study, it was found that there was no statistically significant difference between the level of education and the incidence of PE. This finding is consistent with the results of the Chang study ${ }^{24}$ but contradicts the results of the Herrera study in which there was a significant relationship between literacy level and PE. ${ }^{17}$ Perhaps the reason for this difference is in the type of population studied in the two studies above. In the Herrera study, samples were collected from hospitals in deprived areas of Pakistan but in the present study, samples were collected from urban centers.

In the present study, it was found that the mean body mass index (BMI) in the case and control groups was not significantly different and this factor could not increase the chance of PE. This finding is consistent with many studies in this area, including the studies of O'Brien and Yan. ${ }^{25,26}$

In the present study, it was found that the presence of proteinuria can significantly increase the chance of 
preeclampsia by up to 3.5 times. Given that proteinuria is one of the major criteria for preeclampsia and was an important factor in selecting individuals to enter the case group, no results were expected and are consistent with all studies in this regard. ${ }^{27-29}$

Our study also found that pregnancy rates did not differ significantly in the incidence of preeclampsia. This result was consistent with the study of Bourghei ${ }^{30}$ but was not consistent with the study of Caroline, which may be due to the discrepancy in the sampling method. ${ }^{31}$

In the present study, the mean gestational age of the two groups was not significantly different. This finding was consistent with Hazhir and Shamsi's studies. ${ }^{32,33}$

In our study, the patients in the two groups were not significantly different in the type of pregnancy (single or multiple pregnancies). This finding is consistent with the results of the Chiwora study ${ }^{34}$ but contradicts the Vidya study, which was the most important reason for the difference in the sample size of multiparous women in the study. ${ }^{35}$

\section{Limitations}

One of the notable limitations of this study was the lack of full cooperation of some patients for follow-up and clinical care, due to the prolongation of the time under supervision, which was resolved with full justification of the patients. Also, the small number of patients with preeclampsia during the research period was another limitation of the research.

\section{Conclusions}

The results of this study showed that urinary tract infections in the early months of pregnancy can be associated with an increased risk of preeclampsia. Therefore, it is necessary to reduce the risk of preeclampsia in the coming months by controlling and treating urinary tract infections during pregnancy during timely and timely treatment.

\section{Abbreviations}

UTI, Urinary tract infection; LBW, Low Birth Weight; PE, Preeclampsia; ASB, Asymptomatic Bacteriuria; SPSS, Statistical Package for Social Science.

\section{Data Sharing Statement}

The dataset used and/or analyzed during the present study is available from the corresponding author upon reasonable request.

\section{Ethical Standards}

This study has an ethics code number (IR.SHMU. REC.1397.85) from the research deputy of Shahroud University of Medical Sciences.

\section{Informed Consent}

Informed consent was obtained from all individual participants included in the study.

\section{Consent for Publication}

All named authors have seen and agreed on the submitted version of the paper. All persons in the acknowledgments section have agreed to that inclusion.

\section{Acknowledgment}

The present study was supported by Shahroud University of Medical Sciences as a Medical Doctor (MD) Thesis. We hereby acknowledge the research deputy. Also, we would like to thank all participated patients.

\section{Author Contributions}

All authors of this article have played an active role in all aspects of the preparation of the article, including design, acquisition of data, or analysis and interpretation of data; drafting the article or revising it critically for important intellectual content; gave final approval of the version to be published; and agreement to be accountable for all aspects of the work in ensuring that questions related to the accuracy or integrity of any part of the work.

\section{Funding}

This study received funding from the research deputy of Shahroud University of Medical Sciences.

\section{Disclosure}

The authors declared that they have no conflicts of interest.

\section{References}

1. Binesh E, Mirzaii M, Asadi F, Zolfaghari P, Nikkheslat N, Sohrabi MB. Comparison of the effect of ciprofloxacin and nalidixic acid in the infection of different parts of the urinary tract. Int J Health Stud. 2018;4(2):35-38.

2. MacLean $\mathrm{AB}$. Urinary tract infection in pregnancy. Int $J$ Antimicrob Agents. 2001;17(4):273-276. doi:10.1016/S0924-8579(00)00354-X

3. Girishbabu RJ, Srikrishna R, Rameshs T. Asymptomatic bacteriuria in pregnancy. Int J Biol Med Res. 2011;2(3):740-742.

4. Totsika M, Moriel DG, Idris A, et al. Uropathogenic Escherichia coli mediated urinary tract infection. Curr Drug Targets. 2012;13 (11):1386-1399. doi:10.2174/138945012803530206 
5. Counningham FG, Leveno KJ, Bloom SL. Williams Obstetrics. Vol. 2. 22nd ed. New York: McGraw hill; 2005:1095.

6. Giraldo PC, Araújo ED, Junior JE, Amaral RLGD, Passos MRL, Gonçalves AK. The prevalence of urogenital infections in pregnant women experiencing preterm and full-term labor. Infect Dis Obstet Gynecol. 2012;2012:1-4. doi:10.1155/2012/878241

7. Raza S, Pandey S, Bhatt CP. Microbiological analysis of isolates in Kathmandu medical college teaching hospital, Kathmandu, Nepal. Kathmandu Univ Med J (KUMJ). 2011;9(36):295-297. doi:10.3126/ kumj.v9i4.6348

8. Glaser AP, Schaeffer AJ. Urinary tract infection and bacteriuria in pregnancy. Urol Clin North Am. 2015;42(4):547-560. doi:10.1016/j. ucl.2015.05.004

9. Bánhidy F, Acs N, Puhó EH, Czeizel AE. Maternal urinary tract infection and related drug treatments during pregnancy and risk of congenital abnormalities in the offspring. BJOG. 2006;113:14651471. doi:10.1111/j.1471-0528.2006.01110.x

10. Izadi B, Rostami-Far Z, Jalilian N, et al. Urinary tract infection (UTI) as a risk factor of severe preeclampsia. Glob J Health Sci. 2016;8 (11):54364. doi:10.5539/gjhs.v8n11p77

11. Smaill F, Vazquez JC. Antibiotics for asymptomatic bacteriuria in pregnancy. Cochrane Database Syst Rev. 2015;8:490.

12. Vejdani MH, Gourabchi H, Nahaie MRSM. Study of asymptomatic bacteriuria in pregnant women and antibiotic-sensitivity of isolated bacteria in Tabriz 1996. J Kerman Uni Med Sci. 1998;5(4):165-170.

13. Farajzadegan Z, Mirmoghtadaee P, Mehrabian F. Screening of asymptomatic bacteriuria: urinalysis or urine culture? Which one is more cost- effective? J Isfahan Med Sch. 2008;26(89):119-126.

14. Shirazi MH, Ranjbar R, Daneshyar E, Sadeghian S, Sadeghifard N. Urinary tract pathogens in asymptomatic bacteriuria and their antimicrobial resistance in pregnant women in Hamedan. IJIDTM $J$. 2007;12(36):53-58.

15. Safari M, Yazdanpanah B, Yazdanpanah S. High risk pregnancy and some of related factors in women who referred to vasouj health and medical centers. Sci J Hamadan Nurs Midwifery Fac. 2008;16(2):18-28.

16. Karmon A, Sheiner E. The relationship between urinary tract infection during pregnancy and preeclampsia: causal, confounded or spurious? Arch Gynecol Obstet. 2008;277(6):479-481. doi:10.1007/ s00404-008-0643-2

17. Herrera JA, Chaudhuri G, Lopez-Jaramillo P. Is infection a major risk factor for preeclampsia? Med Hypotheses. 2001;57(3):393-397. doi:10.1054/mehy.2001.1378

18. Easter SR, Cantonwine D, Zera CA, Lim KH, Parry SI, McElrath TF. Urinary tract infection during pregnancy, angiogenic factor profiles, and risk of preeclampsia. Am J Obstet Gynecol. 2015;20(15):93-99.

19. Walker J. Baillieres best pract. Res Clin Obstet Gynaecol. 2000;14 (1):57-71.

20. Zibaeenazhad MJ, Ghodsi M, Arab P, Gholzom N. The prevalence of hypertensive disorders of pregnancy in Shiraz, Southern Iran. Iran Cardiovasc Res J. 2010;4:169-172.
21. Sheraz S, Shahzad S, Boota M. Eclampsia. Prof Med J. 2006;13 (1):27-31.

22. Kumar R, Gandhi S, Rao V. Socio-demographic and other risk factors of pre eclampsia at a Tertiary Care Hospital, Karnataka: case control study. J Clin Diagn Res. 2014;8(9):1-4.

23. Sajith M, Nimbargi V, Modi A, Sumariya R, Pawar A. Incidence of pregnancy induced hypertension and prescription pattern of antihypertensive drugs in pregnancy. Int J Pharm Sci Res. 2014;5(4):163170.

24. Chang F, Armstrong D, Ebeling M, Hulsey I, Newman R. Urinary tract infections are associated with an increased risk of preeclampsia. Am J Obstet Gynecol. 2006;193(6):71. doi:10.1016/j. ajog.2005.10.254

25. O'Brien R, Tara E, Ray G, Wee-Shian B. Maternal body mass index and the risk of preeclampsia. Epidemiology. 2003;14(3):368-374.

26. Yan L, Yu Jin Y, Hang H MD, Yan B. The association between urinary tract infection during pregnancy and preeclampsia a metaanalysis. Medicine (Baltimore). 2018;97(36):e12192. doi:10.1097/ MD.0000000000012192

27. Bánhidy F, Acs N, Puhó EH, Czeizel AE. Pregnancy complications and birth outcomes of pregnant women with urinary tract infections and related drug treatments. Scand J Infect Dis. 2007;39(5):390-397. doi:10.1080/00365540601087566

28. Rezavand N, Veisi F, Zangane M, Amini R, Almasi A. Association between asymptomatic bacteriuria and pre-eclampsia. Glob J Health Sci. 2015;8(7):235-239. doi:10.5539/gjhs.v8n7p235

29. Trogstad LJ, Eskild A, Bruu AL, Jeansson S, Jenum PA. Is preeclampisia an infectious disease? Acta Obstet Gynecol Scand. 2001;80 (11):1036-1038. doi:10.1034/j.1600-0412.2001.801112.x

30. Bourghei N, Kashani E, Rabiei M. The relation between asymptomatic bacteriuria and preeclampsia. J Gorgan Univ Med Sci. 2004;6 (1):56-61.

31. Caroline M, Sara L, David J, Oona C, Liam S. Acute maternal infection and risk of preeclampsia: a population-based case-control study. PLoS One. 2013;8(9):1-8.

32. Hazhir S. Asymptomatic bacteriuria in pregnant women. Urol J. 2007;4(1):24-27.

33. Shamsi U, Hatcher H, Shamsi A, Zaberi N, Qadri Saleem S. Multicenter matched case control study of risk factors for preeclampsia in healthy women in Pakistan. BMC Women Health. 2010;10 (3):19-21. doi:10.1186/1472-6874-10-14

34. Chiwora FM, Fruhauf J, Sculz M, Wacker J, Bastert G, Solomayer E. Seasonal change in the incidence of preeclampsia in Zimbabwe. Acta Obstet Gynecol. 1998;77(7):712-716. doi:10.1080/j.16000412.1998.770703.x

35. Vidya S. Seasonal variation in the incidence of preeclampsia and eclampsia in tropical climatic conditions. $J$ BMC. 2007;64(4):125129.

\section{Publish your work in this journal}

The International Journal of Women's Health is an international, peerreviewed open-access journal publishing original research, reports, editorials, reviews and commentaries on all aspects of women's healthcare including gynecology, obstetrics, and breast cancer. The manuscript management system is completely online and includes a very quick and fair peer-review system, which is all easy to use. Visit http://www.dovepress.com/testimonials.php to read real quotes from published authors. 